\title{
Watershed Characteristics and Landuse Analysis of Govindsagar Catchment, Lalitpur (UP) India Using Remote Sensing and GIS Techniques
}

\author{
Akram Javed1, Samreen Fatima ${ }^{2}$ \\ ${ }^{1}$ Department of Geology, Aligarh (UP), India \\ ${ }^{2}$ Interdisciplinary Department of Remote Sensing and GIS Applications, AMU, Aligarh, India \\ Email: fati.sam786@gmail.com
}

How to cite this paper: Javed, A. and Fatima, S. (2017) Watershed Characteristics and Landuse Analysis of Govindsagar Catchment, Lalitpur (UP) India Using Remote Sensing and GIS Techniques. International Journal of Geosciences, 8, 1374-1383. https://doi.org/10.4236/ijg.2017.811080

Received: October 10, 2017

Accepted: November 26, 2017

Published: November 29, 2017

Copyright $\odot 2017$ by authors and Scientific Research Publishing Inc. This work is licensed under the Creative Commons Attribution International License (CC BY 4.0).

http://creativecommons.org/licenses/by/4.0/ (c) (i) Open Access

\begin{abstract}
Watershed characteristics and land use/land cover study is necessary, for improved decision-making and for the resource management strategies. The methodology necessitates the provision of the base map from SOI toposheet, delineation of drainage, preparation of slope and flow direction map using ASTER data and for the land use/land cover change detection, visual interpretation has been carried out using IRSP6-LISS-III data of 2005 and 2015. The land use/land cover analysis discloses several categories of land cover as well as land use present in Govindsagar variation from 2005 to 2015. The study area is mainly cramped to cultivated land and uncultivated land which show changes since last decade, there is an increase in cultivated land of about $4.86 \%$ of the geographical area where as uncultivated land (fallow land) shows a decline of $1.61 \%$ of the total geographical area, morphometric analysis reveals that area has impermeable subsurface materials and mountainous relief with dendritic drainage pattern with low surface runoff.
\end{abstract}

\section{Keywords}

Arc GIS10.2, Watershed, Morphometry, Visual Interpretation, Landuse/Landcover

\section{Introduction}

A watershed is an area of land that drains all the streams and rainfall to a common outlet such as outflow of reservoir, bay or any point along a stream channel. The word watershed is sometimes used interchangeably with drainage basin or catchment. The watershed consists of surface water, lakes, streams, reservoir 
and wet-lands and all the underlying ground water. Watershed is important because the stream flow and water quality of river are affected by things human induced or not, happening in the land area above the river outflow point.

Morphometric analysis of watershed gives a quantitative description of the basin geometry to understand initial slope or inequalities in the rock hardness structural controls recent diastrophism, geological and geomorphological history of drainage basin [1] [2] [3].

Systematic description of the geometry of a drainage basin and its stream channel system require measurement of linear aspects of the drainage network, aerial aspects of drainage basin and relief aspects of channel network contributing ground slope. The linear and aerial aspects of measurement are planimetric in nature i.e., treat properties projected upon a horizontal datum plane, whereas relief aspects treats the vertical inequalities of the drainage basin forms [4] [5]. In India, some of the pioneering work on drainage basin morphometry was carried out by Strahler and Horton.

Change analysis of features of Earth's surface is essential for better understanding of interactions and relationships between human activities and natural phenomena. This understanding is necessary for improved resource management and improved decision-making. Changes in land cover/land use in watershed area including urbanization and $\mathrm{de}(/ \mathrm{re})$ forestation continuously affect the water availability and phenomena related to it.

Watershed management is necessary because a watershed is not merely a hydrological unit but also socio-ecological being. Therefore, the main objective of the present research was to utilize GIS and Remote Sensing applications to discern the extent of changes occurred in Govindsagar catchment, Lalitpur (UP), India over 10 years' time period.

The specific objectives of the present study are:

- To identify and delineate different LU-LC categories and pattern of land use change in watershed from 2005 to 2015.

- To examine the potential of integrating GIS with RS in studying the spatial distribution of different LU-LC changes.

- To determine the shift in LU-LC categories through spatial comparison of the LU-LC maps produced and to know the overall catchment characteristics.

- To analyze basin morphometric characteristics through linear, aerial and relief parameters.

\section{Study Area}

Govindsagar dam is located on Shehzad River in Lalitpur district of Uttar Pradesh, it is about $3.5 \mathrm{~km}$ long with an average capacity of 96.8 M.c.m. This dam is the main source of irrigation in the nearby area. It is one of the oldest dam based on Siphon technology. The catchment covers an area of $388.63 \mathrm{~km}^{2}$ and lies $24^{\circ} 41^{\prime} \mathrm{N}$ to $24^{\circ} 72^{\prime} \mathrm{N}$ latitude and $78^{\circ} 29^{\prime} \mathrm{E}$ to $78^{\circ} 47^{\prime} \mathrm{E}$ longitude. The maximum and minimum elevations encountered in the water-shed are $531 \mathrm{~m}$ and $335 \mathrm{~m}$ above 
MSL, respectively. The main hydrogeomorphic units of the study area are moderately buried pediplain, valley fills and pediment Inselberg complex. Rock type is mostly crystalline mostly granites with some basic dykes whereas some rocks of sedimentary origin are also present like sandstone, shale and carbonate rocks and very little amount of alluvial valley fills are found. The drainage in the area is sub dendritic with moderate drainage texture. The climate of the study area is sub humid with an average rainfall of $872 \mathrm{~mm}$ (2012). The maximum temperature rises up to $45.5^{\circ} \mathrm{C}$ in May while minimum temperature can be as low as $4.1^{\circ} \mathrm{C}$ in January. Lalitpur represent a typical rain fed area, in which about $91 \%$ of rainfall takes place during June to September.

\section{Data Used}

Geocoded False Color Composite (FCC) of IRS-P6 LISSIII (Path/row: 98/54) having spatial resolution of $23.5 \mathrm{~m}$ of 2005 and 2015 was used. The band combination in FCC is 2 (green), 3 (red), 4 (NIR) were used to derive information of landuse landcover. Data sets corresponds to the same season (i.e., of month February) in order to avoid the seasonal variation. The SOI toposheet no. $54 \mathrm{~L} / 6$ and $54 \mathrm{~L} / 7$ (scale 1:50,000) of 1983-84 used for the preparation of base map and also to extract the drainage which was later updated using the satellite imagery of 2015. For the elevation data and to prepare the elevation and slope map, data from ASTER in $30 \mathrm{~m}$ resolution was used. Besides secondary information about the study area including the geology, hydrogeomorphology, soil type etc was collected from published and unpublished Govt sources.

\section{Methodology}

Review of literature and collection of information about the study area, is the first step in any research, hence it was followed for the study. Base map was prepared using mosaiced SOI toposheet by digitizing major features using ArcGIS10.2. Second step was to drive the elevation information and preparation of slope and elevation map from ASTER DEM. Other maps including hydrological, geological were prepared by digitizing georeferenced maps published by CGWB and GSI using polygon tool in ArcGIS10.2. The drainage map was prepared by demarcating the watershed boundary with the information derived from the data of ASTER DEM and drainage streams were digitized from the mosaiced SOI toposheet and creating up a drainage layer, using ArcGIS10.2. The morphometric parameters of linear, aerial and relief such as stream length, bifurcation ratio, drainage density, stream frequency, drainage texture, relief ratio, basin shape, form factor, circulatory ratio, elongation ratio, compactness coefficient length of overland flow, infiltration ratio were computed using standard methods and formulae by [6] [7] [8] [9].

For the landuse/landcover analysis, standard visual image interpretation has been followed based on photographic and geotechnical elements such as tone, texture, size, shape, association, and field knowledge as well to delineate the var- 
ious categories for both the years i.e., of 2005 and 2015 on IRS-P6 LISS III data. The Govindsagar Catchment has been categorized into seven classes of LU/LC as follows:

- Cultivated land;

- Fallow land;

- Water body;

- Culturable waste land;

- Stone quarry;

- Built-up land;

- Stony waste.

There are various methods to bring out the landuse/landcover analysis like digital classification both by supervised and unsupervised means but here in this study the visual interpretation method is used as the study area is so much fragmented so it seems to be the suitable method to delineate the landuse of Govindsagar catchment. Pre-field interpretation was followed by field/ground truth verification in key areas. Field inputs were incorporated in the LU/LC maps and the maps derived from 2005 and 2015 IRS data were scanned, georeferenced and finally digitized in GIS environment. Each LU/LC category was assigned a unique polygon id in ArcGIS. The coverage was edited, cleaned, polygon topology was built. Drainage map was also digitized and unique ids were assigned to various stream orders.

ArcGIS 10.2 is used to prepare the landuse/landcover map by using the polygon tool, however information from Google earth also used. And then calculations are done both in terms of geographical area and in terms of square kilometers. In order to study the changes in landuse during the decade, map to map comparison was used. Finally, taking into consideration of morphometric analysis, landuse landcover analysis and the information of the secondary data, catchment characteristics were inferred.

\section{Results and Discussions}

\subsection{Morphometric Analysis}

Calculated values of linear, areal and relief aspects of Govindsagar catchment is given in Table 1 and drainage map is shown in Figure 1.

\subsubsection{Linear Aspects}

Based on the analysis of linear aspects it was inferred that the drainage pattern of the study area is sub dendritic, variation in stream length ratio primarily due to differences in slope and topographic conditions. The values of bifurcation ratio of the catchment ranges between 2.00 to 4.00 which indicates less structural control on the drainage development i.e., the drainage of the study area has not been distorted because of tectonic activities.

\subsubsection{Areal Aspects}

A high drainage density value indicates the presence of impermeable subsurface 
Table 1. Morphometric analysis of Govindsagar catchment.

\begin{tabular}{cc}
\hline Basin parameters & Value \\
Mean bifurcation ratio & 3.68 \\
Drainage density (D) & 1.68 \\
Drainage texture (Dt) & 4.56 \\
Stream frequency (Fs) $\left(\mathrm{km}^{-1}\right)$ & 1.86 \\
Basin shape (Bs) & 2.25 \\
Form factor (Rf) & 0.39 \\
Circulatory ratio (Rc) & 0.19 \\
Elongation ratio (Re) & 0.71 \\
Length of overland flow (Lg) $(\mathrm{km})$ & 0.29 \\
Constant channel maintenance $(\mathrm{C})$ & 0.59 \\
Compactness coefficient & 2.28 \\
Relief (R) & 196 \\
Relief ratio (Rh) & 6.26 \\
Ruggedness number $(\mathrm{Rn})$ & 2.58 \\
\hline
\end{tabular}

material and mountainous relief of the catchment. The stream frequency in the area exhibit the correlation with the drainage density, indicating the increase in drainage population with respect to increase in density of drainage. The values of basin shape, form factor, circulatory ratio, elongation ratio and length of overland flow suggest that basin is moderately elongated with moderate relief. Further, catchment has flat peak flows with low surface runoff. The value of constant channel maintenance indicates that $0.59 \mathrm{~km}^{2}$ is requires in the catchment area for creation of linear foot of the stream channel.

\subsubsection{Relief Aspects}

The values of relief aspects indicated the Govindsagar catchment has low to moderate relief and slope. And, Ruggedness number value suggest, low to moderate soil erosion in the study area.

\subsection{DEM and Drainage Relationship}

The highest elevation in study area is $531 \mathrm{~m}$ and the lowest is $335 \mathrm{~m}$. Drainage network is relatively sparse at high elevation areas compared to the areas of low elevation. Unlike high elevation region in the catchment, low elevation region shows dense drainage pat-tern. Streams are long in areas of high elevation and mostly of 1 and 2 order, whereas in low elevation areas streams are shorter and of both lower and higher order. The direction of flow of water can also be predicted from the elevation data is form higher to lower elevation areas.

\subsection{Geology and Geomorphology}

Geologically the area is occupied mostly by crystalline rocks of Archean group in 


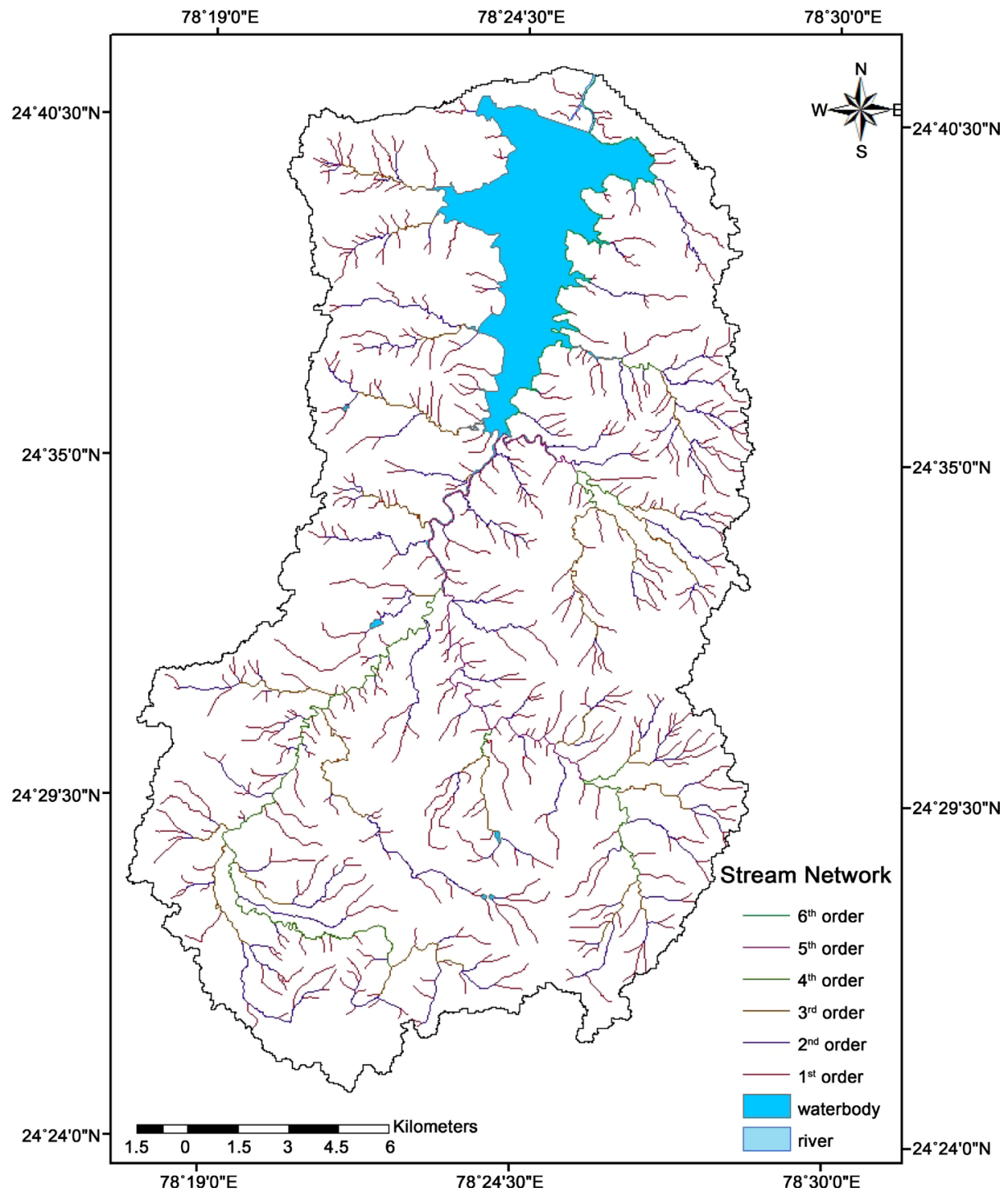

Figure 1. Drainage map of study area.

the north including genies and schist. The southern part have sedimentary rocks like sandstone and shale of Vindhyan. There are 7 hydro geomorphic units, out of which moderately weathered buried pediment and pediment Inselberg complex covers most of the part of Govindsagar catchment (CGWB).

\subsection{Landuse/Landcover Analysis and Change Detection}

LU/LC of the Govindsagar catchment obtained from 2005 and 2015 IRS data is show in Figure 2 and Figure 3.

The statistics of each LU/LC category in terms of both geographical as well as percentage change in each category from 2005 to 2015 is also computed and shown in Table 2. The contrast between the changes of the decade is shown in Figure 4.

Study area is dominated by cultivated land with tree cover and fallow land which include uncultivated land without tree cover. Changes in the land use of 
Govindsagar catchment during the decade were mostly positive as categories including cultivated land and water body have increased in their areal extent whereas, culturable waste land and fallow land have shown reduction in area. Increase in the quarrying activity results in the decrease of stony.

\section{Conclusion}

Present study reveals that the Remote Sensing and GIS techniques have become indispensable tool in the analytical morphometry and land use/land cover mapping. Efforts should be made to bring uncultivated land (fallow) into cultivated land through various land/soil development methods to be adopted at village level. The catchment should be taken up for other developmental activities such

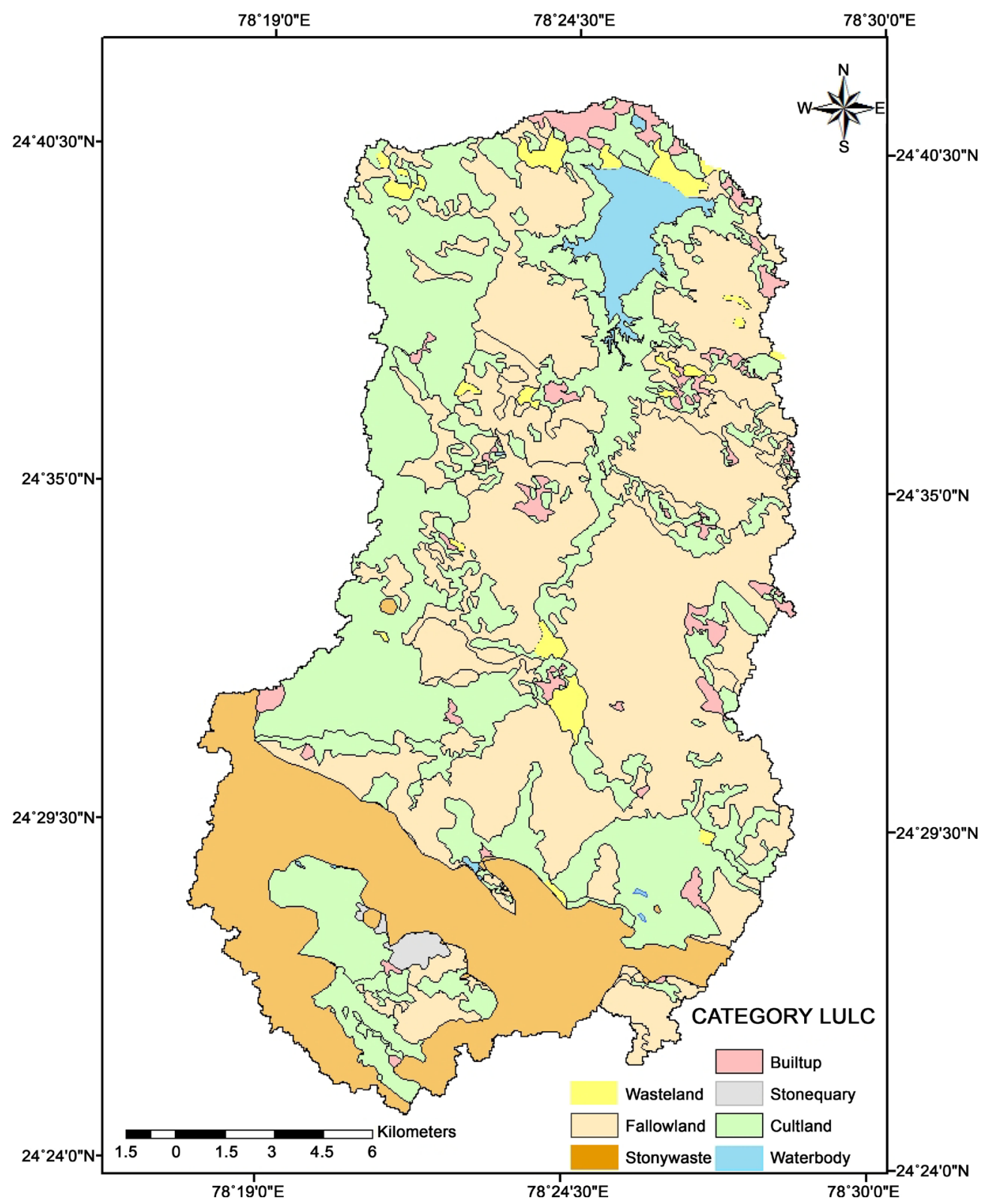

Figure 2. LU-LC 2005. 


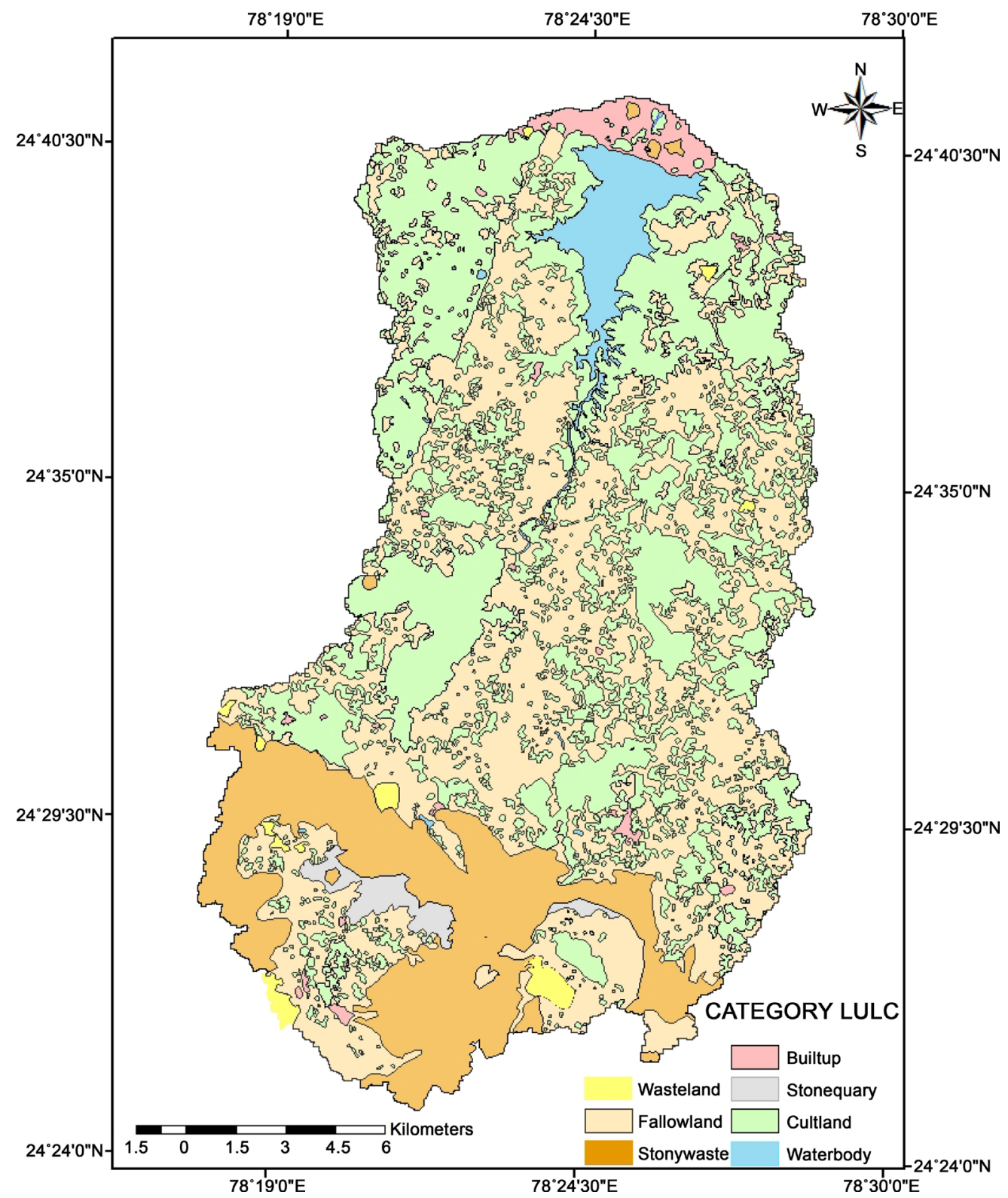

Figure 3. LU-LC 2015.

Table 2. Landuse landcover analysis during the decade.

\begin{tabular}{ccccccc}
\hline Categories & $\begin{array}{c}\text { Area }\left(\mathrm{km}^{2}\right) \\
2005\end{array}$ & Area (\%) 2005 & $\begin{array}{c}\text { Area }\left(\mathrm{km}^{2}\right) \\
2015\end{array}$ & Area (\%) 2015 & $\begin{array}{c}\text { Total change } \\
(\%)\end{array}$ & $\begin{array}{c}\text { Total change } \\
\left(\mathrm{km}^{2}\right)\end{array}$ \\
\hline Culturable wasteland & 7.3 & 1.88 & 3.9 & 0.99 & -0.89 & 0.89 \\
Cultivated land & 123.4 & 31.7 & 142.5 & 36.53 & 18.8 & 4.83 \\
Stony waste & 65.3 & 16.8 & 55.53 & 14.38 & -9.77 & 2.42 \\
Fallow land & 168.1 & 43.2 & 161.6 & 41.59 & -6.5 & 1.61 \\
Built up land & 7.2 & 1.86 & 11.3 & 2.91 & 4.1 & 1.05 \\
Stone quarry & 1.9 & 0.48 & 4.8 & 1.24 & 2.9 & 0.76 \\
Water body & 9.1 & 2.34 & 12.7 & 3.23 & 3.6 & 0.89
\end{tabular}




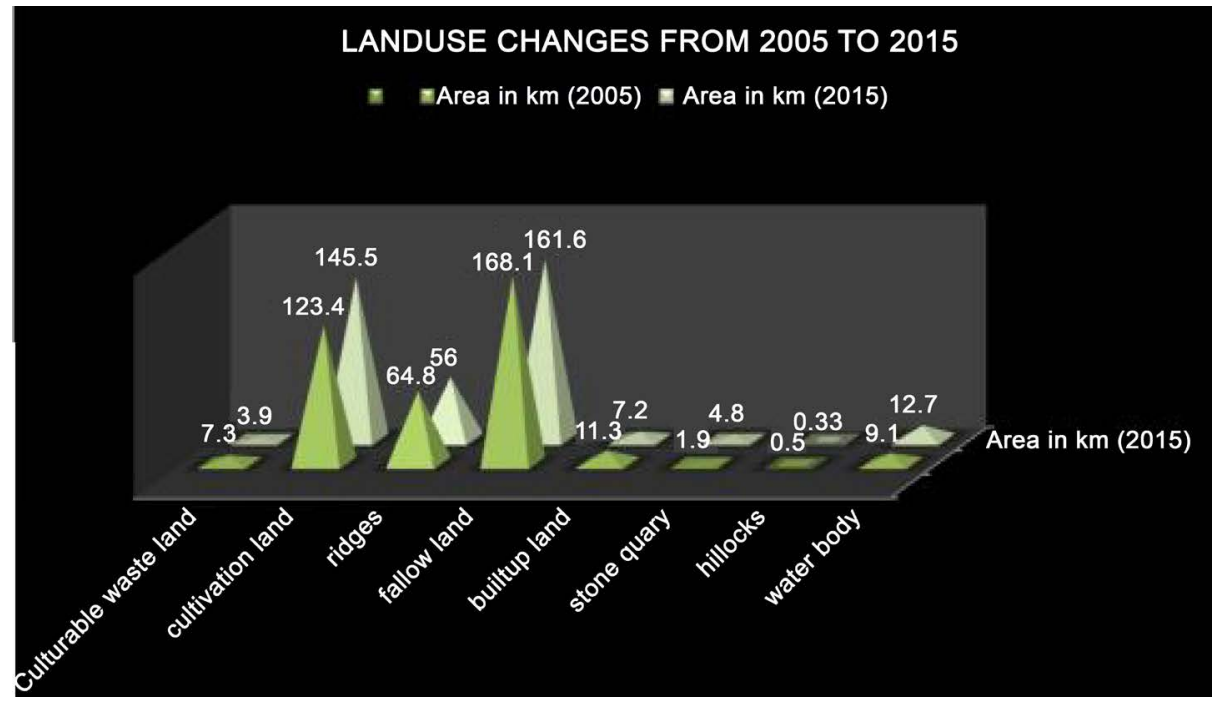

Figure 4. Changes in landuse cover.

as plantation, waste land reclamation, soil conservation and forest regeneration. Further studies at village level are required to develop micro-level plans in the catchment area of Govindsagar Reservoir.

\section{Acknowledgements}

Authors are thankful to the Chairperson of Department of Geology, AMU Aligarh for providing necessary infrastructure facilities. Senior author acknowledges UP Council for Science and Technology for the funding received for the project (CST/SERPD/D-1225). Special thanks to NRSC, Hyderabad for satellite data and USGS for ASTER DEM.

\section{References}

[1] Strahler (1952) Quantitative Geomorphology of Erosional Landscape. 19th International Geological Congress, Algiers, Section 3, Vol. 3, 342-354.

[2] Strahler (1957) Quantitative Analysis of Watershed Geomorphology. Transactions-American Geophysical Union, 38, 913-920.

[3] Strahler (1964) Quantitative Geomorphology of Drainage Basins and Channel Networks. In: Handbook of Applied Hydrology. McGraw Hill Book Company, New York, Section 4-11.

[4] Srivastava, R. and Saxena, R.K. (2004) Technique of Large Scale Soil Mapping in Basaltic Terrain Using Satellite Remote Sensing Data. International Journal of Remote Sensing, 25, 679-688. https://doi.org/10.1080/0143116031000068448

[5] Chow, V.T. (1964) A Handbook of Applied Hydrology. In: Chow, V.T. Ed., $A$ Compendium of Water-Resources Technology, McGraw-Hill Book Company, New York, 43-56.

[6] Sarkar, T.K. and Singh A. (1997) Development of Sustainable Production Base-A Case for Interactive Research and Development. Journal of Soil and Water Conservation, 41, 71-80.

[7] Miller (1953) A Quantitative Geomorphic Study of Drainage Basin Characteristics on the Clinch Mountain Area, Virgina and Tennessee, Proj. NR 389-402, Tech Rep 
3, Columbia University, ONR, New York.

[8] Solanke, P.C. and Prasad, S.R. (2005) Application of Remote Sensing and GIS in Watershed Characterization and Management. Journal of the Indian Society of Remote Sensing, 33, 239-244. https://doi.org/10.1007/BF02990041

[9] Chopra, R., Dhiman, R.D. and Sharma, P.K. (2005) Morphometric Analysis of Sub-Watersheds, District Gurdaspur, Punjab. Journal of the Indian Society of Remote Sensing, 33, 531-553. https://doi.org/10.1007/BF02990738

[10] NRSC; CGWB; IMD.

https://www.nrsc.gov/; http://www.cgwb.gov/; http://www.imd.gov/ 